\title{
Study on the Problems of Chinese Private Enterprises Entering the Research and Production Field of National Defense Science and Technology Industry
}

\author{
Wei Gao \\ School of Management, Harbin Institute of Technology, Harbin, 150001, China \\ gaowei@casic.com.cn
}

\begin{abstract}
Encouraging Chinese private enterprise to enter the research and production of national defense science and technology industry can make full use of scientific and technological achievements and market resources in civilian field, optimize the allocation of resources in national defense science and technology industry, and promote the new system of civilian-military integration. At present, some problems restrict Chinese private enterprise entering the research and production field of national defense science and technology industry. Solving those problems needs China to further optimize the policy environment, set a reasonable market access and exit system, eliminate unreasonable barriers of technical standards, and establish clear communication channels.

Index Terms - private enterprises, the national defense science and technology industry, research and production
\end{abstract}

\section{Introduction}

In the environment of Chinese socialist market economy, it has important significance for the rapid development of national defense science and technology industry to integrate the advantage of market economy and planned economy, take advantage of all available social forces to serve the modernizing of Chinese weapon equipment. After 30 years of development, the private economy has become an important part of the Chinese economy and the briskest economy point of growth in the Chinese economy. Private enterprises make up about $40 \%$ in China top 500 enterprises in 2013. During current and future period, it is the focus and direction of China Defense Reform to encourage the private enterprises to enter construction of the national defense science and technology industry, which has the characteristics of long-term, complexity, and difficulty. It needs to accurately grasp the key problems of private enterprises entering the research and production field of national defense science and technology industry, and establish an efficient operational mechanism, so as to widely guide private enterprises to participate in the research and production of national defense science and technology industry.

\section{Significance of Private Enterprises Entering the Research and Production Field of National Defense Science and Technology Industry}

The main trend of today's world military technology development includes integration of military technology and civil technology and complementary of science and technology resources, and civil-military integration. The Third Plenary
Session of the eighteen Central Committee of the CPC proposed explicitly to promote civil military integration deeply, perfect the system of national defense industry, develop the collaborative innovation system of national defense science and technology, reform the system and mechanism of national defense scientific research and production management and weapon and equipment procurement, and guide the advanced private enterprises to enter the military research, production and repair fields.

There are several advantages to involve civilian technology and industrial base into the construction of Chinese national defense science and technology industry, and encourage private enterprise to enter the research and production of national defense science and technology industry. On one hand, it can make full use of scientific and technological achievements and market resources in civilian field, so as to put more social resources in research and production field of national defense science and technology industry, and expand the foundation of weapons and equipment research and production to improve its development level. On the other hand, it has great significance to further optimize resources allocation of industry of national defense science and technology, break down the military isolated state, reduce repeat construction, promote management system and operational mechanism reform of weapons and equipment research and production, accelerate the formation of orderly competition in military market, and promote the new system of civilian-military integration.

\section{Pathway Analysis to Promote Private Enterprises to Enter the Defense Industry Research and Production Abroad}

After a long-time practice, some countries and regions as USA, Europe and Japan have accumulated a wealth of experiences in promoting private enterprises to participate in the defense industry research and production, and they also have achieved remarkable results.

A. USA: introduce the commercial product standards

By the pathways of adjusting the industry and technology policy, vigorously developing the dual-use technology, introducing a large number of commercial product standards, applying civilian technology and product in weapon systems, promote private enterprises to participate in military research 
and production, USA helps private enterprise develop and reduces the defense procurement budget effectively. In 1994, USA promulgated Federal Acquisition Streamlining Act to allow using as much as possible the dual-use products, technology and industrial practice in national defense industry [1], so as to weak the military standard, introduce the commercial product standards successfully, and promote the commercial off the shelf products to enter the equipment procurement category. It promotes national defense industrial base and civil industrial base to unify, and progresses private enterprises to participate deeply in the defense industry research and production.

\section{B. Europe: cultivate and develop small enterprises}

After the end of the cold war, the main military nations of European cut down defense budget. The procurement funding was substantially reduced while the research and production cost remained high, which poses a dilemma for them. To ensure a healthy development of national defense industry and national economy, Germany actively promotes two-way transfer technology and resources of military and civilian fields by policy, and makes the small enterprises to undertake the task of scientific research and production of national defense industry, which improves the competition ability of national defense industry.

The British Ministry of defense set up defense technology transfer office in 1999, which is committed to make civilian technology serve national defense science and technology. By increasing the national defense scientific research contract number and amount of civil research institutions, especially for those small and medium-sized enterprises, and encouraging advanced civilian scientific research institutions to develop national defense technology [2], it makes small and mediumsized enterprises have accounted for about $60 \%$ share of all research contract from the British Ministry of defense [3].

Defense Order Task Allocation Principle of federal made by Germany defense ministry stipulates that the general contractor must take competition measures to distribute orders to subcontractor, and must let the small and medium-sized enterprises to participate in the competition. The defense department considers it as an important factor to select the general contractor [4].

\section{Japan: Play the role of fiscal, tax and financial polices}

As a typical country of civil military integration, Japanese private enterprises take most tasks of defense research and production. Mitsubishi and Kawasaki and other large enterprises with military research and production capacity have joined the world military top 100 ranks [5]. In the process of promoting private enterprises to develop, fiscal, tax and financial policies play an important role. The Japanese government offers subsidies for technological innovation projects, 6\% tax-free for the small and medium-sized enterprises to research and develop, and reduces the corporate tax for aircraft and weapons manufacturing enterprises and relevant subcontractor. It sets up different types of state-owned policy financial institutions to urge private enterprise undertaking the defense industry research and production [6].

\section{The Problems of Chinese Private Enterprises Entering the Research and Production Areas of National Defense Science and Technology Industry}

\section{A. Imperfect policy environment}

Along with the development of national defense science and technology China industrial policy adjustment, has promulgated a series of policies to let private enterprise to enter the defense science and technology industry research and production. For example, in 2005 February, the State Council promulgated the State Council on encouraging, supporting and guiding the individual and private and other non-public economic development in a number of opinions, put forward: "to allow non-public capital to enter the field of science technology and industry for national defense construction", which opened the private enterprises to enter the military research and production area of the door in policy [7]. In 2012 July, the national defense science and industry, general equipment department jointly issued the Implementation Opinions on Encouraging and Guiding the Private Capital Entering the Field of National Defense Science and Technology Industry, put forward to attract and encourage private capital into the research and production of weapons and equipment, technology and industry for national defense construction investment, dual-use technology development and national defense science and technology industry [8]. In the policy driven, China battalion enterprise to enter the defense science and technology industry research and production has made important progress, more than 1000 private enterprises has obtained the weapons and equipment research and production license. Private enterprises to participate in weapon equipment procurement competition range, gradually from the components, parts, extending to the host, has become a new force to promote the scientific development of weaponry construction.

Although encouraging Chinese private enterprises to enter the national defense science and technology industry research and production field of policy to gradually open up, but there are still some rooms for improvement. For example, there are policy conflicts, The Interim Regulations on Private Enterprise Twelfth stipulation: the private enterprise shall not be engaged in military industry, the financial industry production and management. At the same time, investment, tax policy is not perfect, China military construction funds for technological transformation, the scientific research project funds can not be directly to private enterprises, only 11 kinds of specific products of private enterprises in production at the assembly part exempt from value-added tax. These problems have seriously affected the enthusiasm of private enterprises to participate in the industry of national defense science and technology research and production [9].

\section{B. Leaky market access and exit system}

The first thing is hard to access to market. In accordance with the provisions of the China policy, the non-public 
enterprises, who engaging in research and production of weapons and equipment within the scope of scientific, should acquire research and production license of weapons and equipment, security certification, and quality system certification. And the production condition should be safe. But most of private enterprises are small scale without enough capital. In China top 500 private enterprises in 2013, the highest income is 232.723 billion Yuan, while the lowest 7.772 billion Yuan, and the average is 20.993 billion Yuan. To meet the requirement mentioned above, private enterprises have to go through a long, complex and difficult period. It seriously affects the enthusiasm of private enterprise to join in.

The second thing is the market system is not perfect. In existing policy, there is not any regulation for involved private enterprises to exit but only regulation stressing the punishment if they violate laws and regulations or the contract in the project implementation process. Still, there is no specification for private enterprises of withdraw permission and exit program [11].

\section{Technical standards barriers}

Due to their particularity, weapon and equipment follow strict production standards and norms, which lead to different technology standards between national defense industry and civil field. Dual track system of military and national standards hinder technology transferring between the of military field and civilian field, and it brings high cost to private enterprises entering the research and production field of national defense science and technology industry. When they engage military research and production in accordance with the military standard, private enterprises have to improve and reform the production equipment, personnel structure and management style. And this requires a lot of investment. Meanwhile, the operational risks increase during the military research and production, because the different interpretations of standard technical index are easy to cause anti-compliance phenomenon [12].

\section{Blocked channels of information communication}

The special purpose of military decides the confidentiality of military research and production. At present, China has not yet established a military supply and demand information release system and platform. Accordingly, it could not fully disclose information when issuing bidding announcement. And without name list of all the qualified private enterprises, government can only choice the handful enterprises on Weapon and Equipment Manufacturer Directory, which leads to information asymmetry among different producers on bidding announcement, process and mode of military production. Limited by their identity, private enterprises cannot get demand information officially. If they obtain information from abnormal channels, they are likely to fail in bidding and even raise operational risk because of information distortion in timeliness, accuracy and integrity [13].

\section{The Recommendations of Chinese Private Enterprises Entering the Research and Production Areas of National Defense Science and Technology Industry}

The most fundamental reason for those problems is that China has concerns about private enterprises, and emphasis on the particularity of the national defense science and technology industry market. It can be subdivided into two reasons. The first is economy reason. National defense science technology and industry market is thought to be limited. There should not to be excessive market participants in order to formulate scale economy. The second thing is security reason. The weapons and equipment are the output of national defense science and technology industry market. To ensure the national security strategy and stability of military weapons and equipment supply, the quantity of market main body must be limited and the quality should be reliable. The state-owned enterprise is the best choice since private enterprises are not reliable [14]. In order to solve the problems above, the countermeasure and suggestion frame with reasons' analysis is put forward as shown in figure 1.

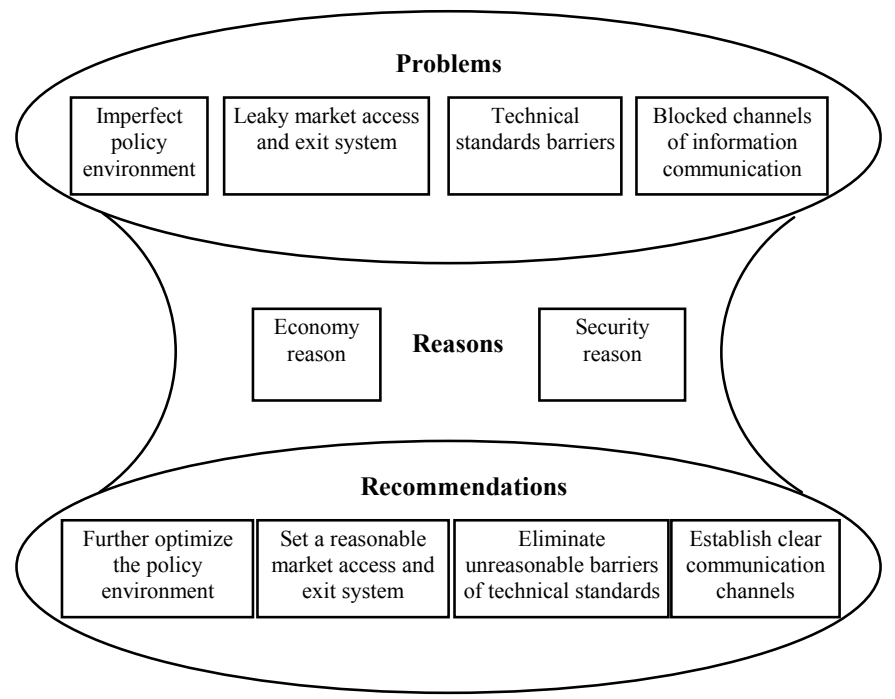

Fig. 1 Recommendations diagram of promoting private enterprises to participate in the research and production of national defense science and technology industry.

\section{A. Further optimize the policy environment}

The first thing is to attract Chinese private enterprises to participate in the defense field by preferential policies. For example, formulate preferential tax policies to appropriately relief private enterprises of military production tax, and make them enjoy the same tax treatment as military enterprises. For the high-tech private enterprises who undertake the task of weapons and equipment research and production, can enjoy the high-tech enterprises preferential policy once being confirmed.

The second thing is to constantly improve the policy environment of military investment. Issue Catalogue for 
Guiding Social Investment in Military Field, dividing investment field into open class, restricted and prohibited categories, which would provides the reference for the private economy when entering the military market. Actively explore a variety of financing channels and diversified financing methods, such as equity financing, bond financing, stock financing, and widely use domestic and international financial market and the capital market to make capital market of military and civilian unite.

\section{B. Set a reasonable market access and exit system}

The first thing is to establish a more flexible access system. In the aspect of legislation, modify related laws and regulations, such as The Interim Regulations on Private Enterprise and National Defense Law, and cancel the terms which prohibit or restrict the private enterprises to enter the military research and production. Apply classification management on the military market according to the importance and exclusive of assets and specific. Regard to those private enterprises with low degree military secrecy, as long as they do not involve national security and public interests, they can be out of restriction by three certificates-research and production license of weapons and equipment, security certification, quality system certification, and can be encouraged more to participate in military research and production. If their products are just matching products or raw materials and not involving military technical secrets, the private enterprises no need to implement security certification.

The second thing is to improve the withdrawal system. For those private enterprises to be out of the military research and production, explore to establish a system that allow military enterprises to extract the military technology part from the private enterprise by means of acquisition and merger, etc. It can effectively protect military technology and further promote the integration of national defense science and technology resources.

\section{Eliminate unreasonable barriers of technical standards}

The first thing is to reform double track system of military standards and national standards, and regularly modify the less sophisticated military standard to further optimize the military standard system.

The second thing is to introduce system to define the civil standard military directory by issuing the policy of Encouraging Civil Standards in Military Productions, and expand the application scope of civil standard in the field of weapons and equipment research and production.

The third thing is to encourage the advanced Chinese private enterprises and military enterprises to participate in the formulation of national standards, and promote the military standard and national standard to integrate at the strategic level.

\section{Establish clear communication channels}

Establish information exchange platform and qualified private enterprises database. According to the requirements of weapon equipment construction in China, select advanced and mature civil technology. Management department in charge of equipment issues information through procurement information exchange platform to private enterprises which have entered in the database. Regularly organizes technical docking activities to establish smooth communication channels to make the supply from private enterprises meet the demand from army units and enterprises.

\section{References}

[1] Xuanting Ye, Yun Liu. America to promote the development of civil military integration mode and Its Enlightenment to China, Basic Defense Technology, pp. 16-20, April, 2007.

[2] Xiaoyan Di, Tiecheng Guo. Characteristics and Enlightenment of British innovation policy, Technology and Law, pp. 38-40, January, 2012.

[3] Jieguang Zheng. The Strategy of British national defense industry development, National Defense Science and Technology Industry, pp. 37-39, March, 2011.

[4] Yang Yu. Status of Germany's defense industry development, Ship Materials and Market, pp. 26-29, January, 2009.

[5] Zhaozhen Fan. Japan's defense industry financial support mode perspective, Northeast Asia forum, pp. 18-21, March, 2009.

[6] Yin Gu, Jianqiang Ji. Major Asian countries of civil military integration analysis - type of defense research investment in Japan and India as an example, Technology Wind, pp. 32-33, October, 2011.

[7] State Council. About encouraging, supporting and guiding the individual and private and other non-public economic development in a number of opinions, August, 2005, http://www.gov.cn/zwgk/200508/12/content_21691.htm

[8] National defense science and industry agency. the Implementation Opinions on Encouraging and Guiding the Private Capital Entering the Field of National Defense Science and Technology Industry, November, 2012, http://www.sastind.gov.cn/n137/n243/c39131/content.html

[9] Renhuai Du, Lin Wang. Institutional guarantee for developing of privately military industrial enterprises, aerospace industry management, January, 2014.

[10] Jie Li, Xiaosong Li, Xiaorong Ye. Research on the private enterprises entering weapon system research and production area, Military Equipment Academy Journal, January, 2013.

[11] Jintao Chen, Rui He. The strategic potions of private enterprises entering national defense production, Economic Research Publication, August, 2012.

[12] Yong Xu, Siqi Liu. research on benefit-oriented mechanism of militarycivil integration. Review of the Air Force Academy, January, 2014.

[13] Han Zhao, Yu Liao. Operation and management analysis of the civilmilitary integration equipment technique E\&D. Review of the Air Force Academy, January, 2014.

[14] Xiaoge Wen, Wenbo Zhu. The study on Chinese defense science and technology industry management innovation in the policy of civilmilitary integration. Review of the Air Force Academy, January, 2014. 